\title{
The severity of temporomandibular joint disorder by teeth loss in the elderly
}

\author{
Indry Herdiyani*), Erna Kurnikasari*, Lisda Damayanti* \\ *Department of Prosthodontics Faculty of Dentistry Universitas Padjadjaran Bandung
}

\begin{abstract}
Temporomandibular joint dysfunction is a term that covers a number of clinical problems that involves masticatory muscles, temporomandibular joints and related structures, or both. Loss of tooth was an etiology of temporomandibular joint dysfunction. The purpose of this study was to obtain the description of temporomandibular joint dysfunction level that caused by tooth loss of elderly in three nursing home Bandung. This was a descriptive study using the survey method of the elderly in three nursing home Bandung. A total of 34 people consist 6 males and 28 females. The subjects were examined by symptoms of temporomandibular joint dysfunction and the dysfunction level was assessed by Helkimo Clinical Dysfunction Index. The result of this study show that elderly in Nursing Home Bandung have mild dysfunction level were $7(14.71 \%)$, moderate dysfunction level were $22(64.71 \%)$, and severe dysfunction level are $5(20.58 \%)$. It can be concluded that loss of the teeth is one of the etiologies of temporomandibular joint disorder. Based on the research conducted, it can be concluded that all elderly with teeth loss will have temporomandibular joint disorder and the most severity happens based on teeth loss by using the Helkimo Clinical Disfunction Index score was the moderate disorder.
\end{abstract}

Key words: Temporomandibular joint dysfunction, tooth loss, elderly

\section{ABSTRAK}

Gangguan sendi temporomandibula adalah istilah yang mencakup sejumlah masalah klinis yang melibatkan otot-otot pengunyahan, sendi temporomandibula dan struktur yang terkait atau keduanya. Salah satu penyebab gangguan sendi temporomandibula adalah kehilangan gigi. Tujuan penelitian ini untuk melihat gambaran tingkat keparahan gangguan sendi temporomandibula berdasarkan kehilangan gigi pada lansia di tiga Panti Sosial Tresna Wredha Kota Bandung. Jenis penelitian yang digunakan adalah deskriptif dengan metode survei terhadap lansia di tiga Panti Sosial Tresna Wredha kota Bandung. Jumlah sampel adalah 34 orang yang terdiri dari 6 orang laki-laki dan 28 orang perempuan. Data diperoleh melalui pemeriksaan klinis gejala-gejala gangguan sendi temporomandibula dan tingkat keparahan gangguan sendi temporomandibula dinilai dengan menggunakan indeks disfungsi klinis Helkimo. Hasil penelitian menunjukkan bahwa tingkat keparahan gangguan sendi temporomandibula ringan terjadi pada 7 orang (14,71\%), gangguan sedang pada 22 orang (64,71\%) dan gangguan berat pada 5 orang (20,58\%). Dapat disimpulkan bahwa pada lansia dengan kehilangan gigi akan mengalami gangguan sendi temporomandibula, dan derajat keparahan berdasarkan kehilanganan gigi menggunakan Helkimo Disfunction Index didapat hasil gangguan sedang. 
Kata kunci: Gangguan sendi temporomandibula, kehilangan gigi, lansia

\section{INTRODUCTION}

Generally, every adult has 32 teeth but many of them experience teeth loss. Loss of the teeth can be caused by various reasons such as caries, periodontal diseases, accident, and also for some deliberate aesthetics purposes, in order to improve appearance or function. ${ }^{1}$

Age can affect the prevalence of teeth loss. The more a person's age, the highest prevalence of teeth loss will be. ${ }^{2}$ Generally, the elderly will experience a reduction in the number of teeth. Even though there is a tendency of an individual to maintain his teeth until he is in his old age, but approximately $10 \%$ of the population will experience edentulous. ${ }^{3}$

Loss of teeth usually determines an important change in the masticatory system which affects the bone structure, oral mucosa, and masticator muscles. ${ }^{4}$ It is also one of the most important factors associated with the increase of temporomandibular joint disorder, primarily the loss of the first maxilla premolar. ${ }^{5}$

According to Tortopidis et al. ${ }^{4}$ the clinical symptoms and signs of temporomandibular joint disorder happen more often to the elderly patients. This is related to the patients' general health, head position, masticatory efficiency and the occlusion condition. ${ }^{4}$

The cause of temporomandibular joint disorder is very complex and is still in debate. ${ }^{6}$ Previous researchers argue that temporomandibular joint disorder may be caused by the loss of teeth's support and the increase of burden that produce some changes such as disc shifting and degenerative joint disorders. ${ }^{7}$ Pullinger $^{8}$ suggests that the loss of posterior teeth is one of the predisposition factors of the temporomandibular joint disorder symptoms. According to DeBoever and Carlsson ${ }^{8}$, lack of molar support is a perpetuation factor of temporomandibular joint disorder. ${ }^{8}$

The severity of temporomandibular joint disorder can be measured by using Helkimo Disfunction Index $(\mathrm{Di})$ which is classified into four index scales, that is no disorder (Di 0), low disorder (Di I), moderate disorder (Di II), and high disorder (Di III). ${ }^{9}$
Based on the description above, the authors are interested in conducting a research on the elderly experiencing teeth loss in Tresna Wredha Nursing Homes located in Bandung in order to find out the severity of temporomandibular joint disorder occurred.

\section{METHODS}

This study was a descriptive study case. The population was the elderly in three Tresna Wredha nursing homes in Bandung. The samples were taken based on the purposive sampling in accordance with the population criteria determined by the authors. The criteria were, willing to participate in the research, cooperative, aged over 60 years old, teeth loss in the oral cavity, and didn't wearing removable or fixed prostheses.

The data was collected by clinical examination of some symptoms of temporomandibular joint disorder and was assessed using the Helkimo Clinical Disfunction Index, then processed in order to illustrate the severity of temporomandibular joint disorder based on teeth loss in the elderly.

\section{RESULTS}

From the results of the research conducted to 34 elderly comprises 6 males and 28 females, it was found that the most group age of the elderly was 75-90 years old group age, as many as 18 people (52.94\%).

The distribution of the number of missing

Table 1. Distribution of the research subjects based on the number of missing teeth

\begin{tabular}{ccc}
\hline $\begin{array}{c}\text { Total tooth } \\
\text { lost }\end{array}$ & $\mathrm{n}$ & $\begin{array}{c}\text { Precentage } \\
\text { (\%) }\end{array}$ \\
\hline $1-5$ & 3 & 8.82 \\
$6-10$ & 5 & 14.72 \\
$11-15$ & 4 & 11.76 \\
$16-20$ & 4 & 11.76 \\
$21-25$ & 3 & 8.82 \\
$\geq 26$ & 15 & 44.12 \\
\hline Total & 34 & 100.00 \\
\hline
\end{tabular}


Table 2. The severity of temporomandibular joint disorder by age group

\begin{tabular}{ccccc}
\hline $\begin{array}{c}\text { Temporomandibular } \\
\text { joint disorder }\end{array}$ & $\mathbf{6 0 - 7 4}$ & $\mathbf{7 5 - 9 0}$ & $>90$ & Total \\
\hline Di I & 3 & 4 & 0 & 7 \\
Di II & 9 & 11 & 2 & 22 \\
Di III & 2 & 3 & 0 & 5 \\
\hline Total & 14 & 18 & 2 & 34 \\
\hline
\end{tabular}

Table 3. The severity of temporomandibular joint disorder by sex

\begin{tabular}{cccc}
\hline $\begin{array}{c}\text { Temporomandibular } \\
\text { joint disorder }\end{array}$ & L & P & Total \\
\hline Di I & 4 & 3 & 7 \\
Di II & 2 & 20 & 22 \\
Di III & 0 & 5 & 5 \\
\hline Total & 6 & 28 & 34 \\
\hline
\end{tabular}

Table 4. The severity of temporomandibular joint disorder by the number of the teeth loss

\begin{tabular}{|c|c|c|c|c|c|c|c|}
\hline \multirow{2}{*}{$\begin{array}{c}\text { Temporomandibular } \\
\text { Joint disorder }\end{array}$} & \multicolumn{6}{|c|}{ Total teeth lost } & \multirow{2}{*}{ Total } \\
\hline & $1-5$ & $6-10$ & $11-15$ & $16-20$ & $21-25$ & $>26$ & \\
\hline $\mathrm{Dil}$ & 2 & 0 & 0 & 1 & 1 & 3 & 7 \\
\hline Di II & 1 & 5 & 3 & 2 & 2 & 9 & 22 \\
\hline Di III & 0 & 0 & 1 & 1 & 0 & 3 & 5 \\
\hline Total & 3 & 5 & 4 & 4 & 3 & 15 & 34 \\
\hline
\end{tabular}

teeth in the elderly can be seen in Table 1, most of the elderly have lost more than 26 teeth, as many as $44.12 \%$. Table 2 shows the temporomandibular joint disorder mostly occurs in every group age of the elderly is the moderate disorder (Di II). Table 3 shows the temporomandibular joint disorder mostly occurs in elderly women than elderly men. Table 4. Shows the moderate disorder (Di II). It is the mostly happened disorder in each number of teeth loss group.

Based on the overall research, Diagram 1 shows the severity of temporomandibular joint disorder by teeth loss in the elderly in three Tresna Wredha Nursing Homes located in Bandung is low disorder $(20.58 \%)$, moderate disorder $(64.71 \%)$, and high disorder (14.71\%).

\section{DISCUSSION}

Ageing is a natural process that cannot be avoided. It runs continuously. This process causes the anatomical, physiological, and biochemical changes in the body so that it will affect the overall body's functions and capabilities. ${ }^{7}$

Based on the research conducted, the average of the missing teeth in the elderly was 20 teeth per person. In other words, there were still another 12 teeth per person. This situation was still too far from the expected national target, that was the average number of remaining teeth in the oral cavity was 20 teeth per person. ${ }^{10}$
The symptoms of temporomandibular joint disorder mostly happen in the case of the loss of more teeth than in the case of one tooth loss due to the masticatory muscles receive heavier burden during the function, so that it affects the structure of temporomandibular joint. ${ }^{11}$ In this research, it was also seen that the more teeth loss, the highest the severity of the temporomandibular joint disorders will be. This was in line with the study conducted by Pullinger et al. ${ }^{2}$ and Tallents, et al. ${ }^{12}$ that assumes the teeth loss was related to temporomandibular joint disorder and its severity. Another study conducted by Pullinger and Seligman ${ }^{12}$ indicates different result. They stated that there was no connection between teeth loss and temporomandibular joint disorder. ${ }^{12}$

The result showed that the mostly occurred severity of temporomandibular joint disorder in

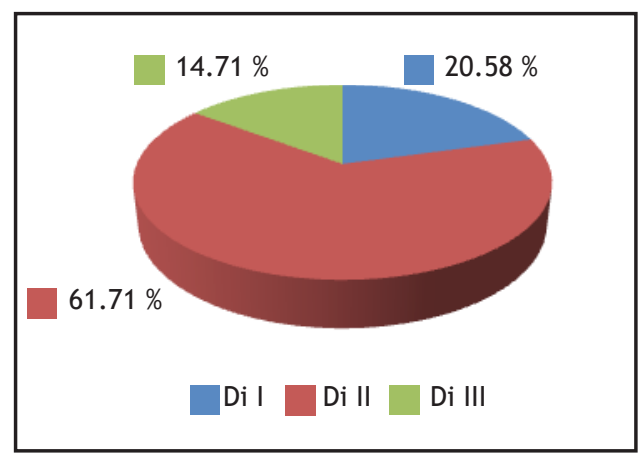

Diagram 1. The severity of temporomandibular joint disorder by teeth loss in the elderly in three Tresna Wredha Nursing Homes in Bandung. 
the elderly was the moderate disorder ( $\mathrm{Di}$ II). This was caused by the symptoms accompanying the temporomandibular joint disorder in light phase, but was at risk of becoming high temporomandibular joint disorder (Di III).

In this study, the severity of temporomandibular joint disorder mostly occurs in elderly women. This was in line with the research conducted by Sarna-Boś et al. ${ }^{13}$ and LeResche et al. ${ }^{14}$ that indicate the temporomandibular joint disorder occurs 2 to 5 times bigger in women than in men. This was caused by the frequency of elderly men that still have bigger teeth than elderly women. Consequently, it reduces the worse risk of the temporomandibular joint disorder severity ${ }^{15}$, and also was affected by the number of female subjects that participate more in the research.

Goldstein and Kapila ${ }^{16}$ stated that temporomandibular joint disorder in women commonly occurs between the puberty age and middle age. The study conducted by Wang et al. indicates that young age has more risk for temporomandibular joint disorder. ${ }^{13}$ But in this research, the elderly have also risk for it.

The severity of temporomandibular joint disorder was proportional to the patients' age. The result showed that temporomandibular joint disorder was closely associated with the teeth loss in group age and also sex factor. This was also supported by the research conducted by Wang et al. ${ }^{12}$ that indicates gender affects the risk of temporomandibular joint disorder.

\section{CONCLUSION}

Loss of the teeth is one of the etiologies of temporomandibular joint disorder. Based on the research conducted, it can be concluded that all elderly with teeth loss will have temporomandibular joint disorder and the most severity happens based on teeth loss by using the Helkimo Clinical Disfunction Index score was the moderate disorder.

\section{REFERENCES}

1. Soratur SH. Essential of prosthodontics. New Delhi: Jaypee Brothers; 2000. p. 127.
2. Tallents RH, Macher DJ, Kyrkanides S, Katzberg RW, Moss ME. Prevalence of missing posterior teeth and intraarticular temporomandibular disorders. J Prosthet Dent 2002;87:45-50.

3. Jubhari EH. Proses menua sendi temporomandibula pada pemakai gigi tiruan lengkap. Cermin Dunia Kedokteran; 2002;137:42-5. [cited 2010 Apr 26]. Available from: http://www. kalbe.co.id. 2002.

4. Hotta PTH, Hotta TH, Bataglion C, Pavao RF, Siéssere S, Regalo SC. Bite force in temporomandibular dysfunction (TMD) and healthy complete denture wearers. Braz Dent J 2008;19(4):354-7.

5. Dodic S, Sinobad V, Obradovic-Djuricic K, Medic V. 2009. The role of occlusal factor in the etiology of temporomandibular dysfunction. Srp Arh Celok Lek. 2009;137(11-12):613-8. [cited 2010 Apr 14]. Available from: http:// www. doiserbia.nb.rs.

6. Tanaka E, Mercuri LG. Degenerative disorders of the temporomandibular joint: etiology, diagnosis, treatment. J Dent Res 2008;87:296307.

7. Maryam RS. Mengenal lanjut usia dan perawatannya. Jakarta: Salemba Medika; 2008. p. 1-3.

8. Harper RP, Misch CE. Clinical indications for altering vertical dimension of occlusion. Quintessence Int 2000;31(4):275-80.

9. Schiffman EL, Anderson GC, Fricton JR, Lindgrenet $B R$. The relationship between level of mandibular pain and dysfunction and stage of temporomandibular joint internal derangement. J Dent Res 1992;71:1812-5.

10. Departemen Kesehatan Republik Indonesia. Pedoman pembinaan kesehatan usia lanjut bagi petugas kesehatan. 1994. Jakarta: Direktorat Jenderal Pembinaan Kesehatan Masyarakat [cited 2010 Aug 29]. Available from: http:// www.depkes.go.id.

11. Okeson JP. Bell's orofacial pains: The clinical management of orofacial pain. $6^{\text {th }}$ ed. St. Louis: Mosby Inc.; 2005. p. 331,335-42.

12. Wang MQ, Xue F, He JJ, Chen JH, Chen CS, Raustia A. Missing posterior teeth and risk of temporomandibular disorders. J Dent Res 2009;88(10):942-5. 